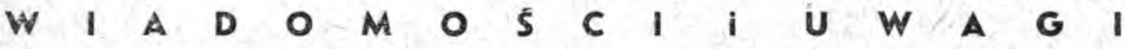

\section{ZMIANY W KODEKSIE RUBRYK}

W Acta Apostolicae Sedis, nr 7 z 1 ozerwca 1961 r. str. 388, ogłoszono nasteppującą deklarację Św. Kongregacji Obrzędów:

\section{DEKLARA C J A}

\section{o wspaminaniu dnia powszedniego 4 klasy}

Ponieważ tej Św. Kongregacji Obrzędów przedstawiono pewne wątpliwości co do wspomnienia dnia powszedniego 4 kilasy w Mszach świętych W szerszym znaczeniu oraz w Mszach wotywnych, dla osiągnięcia większej prostoty w calej sprawie wspomnień, ta Sw. Kongregacja postanowiła zdeklarować:

nigdy nie należy wspominać dnia powszedniego 4 klasy ani w Mszach świątecznych, ani w wotywnych nawet konwentualnych.

W Kodeksie rubryk należy zatem zmienić następujące punkty:

a) n. 26 ma brzmieć: ,Wszystkie dni nie wymienione w numerach 23-25 sạ dniami powszednimi 4 klasy, nigdy się ich nie wspomina".

b) n. 289 na początku ma brzmieć: ,We wszystkie dni powszednie 4 klasy... można odprawiać bez wspomnienia bieżącego dnia powszedniego".

c) Druga część n. 299 ma brzmieć: „W pozostałe dni powszednie odprawia się Mszę z poprzedniej niedzieli, chyba że rubryki przewidują co innego".

Rzym, w siedzibie Sw. Kongregacji Obrzędów, dnia 27 maja 1961.

$\dagger$ K. Kard. CICOGNANI

Bp. Tusculum, Prefekt

Henryk Dante

Sekretarz

\section{JĘZYK POLSKI WE MSZY S̄WIĘTEJ}

\section{SACRA CONGREGATIO RITUUM}

\section{DIOECESIUM POLONIAE}

Prot. N. D. $32 / 961$

Ad humiles enixasque preces E. mi ac Rev. mi Domini Stephani Cardinalis Wyszyński, Archiepiscopi Metropolitani Gnesnen. et Varsavien, Primatis Poloniae, Sacra Rituum Congregatio, utendo facultatibus sibi a Sanctissimo Domino nostro Joanne Papa XXIII tributis, attentis peculiaribus adiunctis in supplicitis libello expositis, benigne indulsit ut 
in Missis cantatis, a populo cantari possit in lingua polonica: Gloria, Credo, Sanctus et Agnus Dei.

In Missis solemnibus lector, subdiaconus vel diaconus, decantatis latine lectione, epistola et evangelio, possit immediate et versus populum eosdem textus in lingua polonica perlegere.

In Missis cantatis ipse sacerdos, perlecta aut decantata lectione vel epistola et evangelio in lingua latina, possit immediate et versus populum perlegere eosdem textus in lingua polonica.

Servatis de cetero servandis. Contrariis quibuslibet non obstantibus. Die 7. Julii 1961.

† C. Card. CICOGNANI

S. R. C. Praef.

Henricus Dante

a Secret.

\section{INSTRUKCJA EPISKOPATU POLSKI}

\section{- wprowadzenie w życie przywileju Stolicy Aposiolskiej $z$ dnia 7 lipca 1961 r.}

Konferencja Episkopatu Polski, na 69 posiedzeniu, przyjęła i podaje do wykonania następującą Instrukcję.

I. SPIEWANIE STAEYCH CZEŚSI MSZY SWIETEJ

1. Teksty Mszy św.: Gloria, Credo, Sanctus wraz z Benedictus, i Agnus Dei mogą byé śpiewane przez wiernych w języku polskim jedynie w przekładzie zatwierdzonym przez Episkopat. Taki tekst tłumaczenila posiadaja wszystkie Kurie Biskupie - przy czym, obok „Credo" mszalnego, dopuszczalne jest „Wierze w Boga..." używane w pa_ cierzu.

2. Do wymienionych tekstów mszalnych można wykonywać jedynie te melodie, które otrzymują aprobate Podkomisji Liturgicznej Episkopatu dla Spraw Muzyki i Spiewu Kośc. Jedna z takich melodii znajduje się w Śpiewniku Parafialnym - Wydawnictwo Kurii Biskupiej - Olsztyn, 1961 - str. 74 nn.

3. Po uzyskaniu przywileju Stolicy Apostolskijej, w miejsce tekstów stałych podczas Mszy św. śp ie w a n y ćh, nie wolno wykanywać innych dowolnych pieśni. Pieśni takie moga być śpiewane tyllko w czasie Mszy św. czytanych, byleby ich treść byla zbliżona do poszczególnych części mszalnych.

UWAGA: Czynny udział wiernych we Mszy św. śpiewanej, jeżeli chodzi o śpiewanie stałych części mszalnych, jest następujący:

Wszyscy wierni śpiewają:

a) po lacinie: liturgiczne odpowiedzi:

Amen,

Et cum spiritu tuo,

Gloria Tibil Domine,

Habemus ad Dominum,

Dignum et iustum est, 